UDC $547.722: 543.341$

\title{
THE SELF-CONDENSATION REACTION OF METHYL-4-CHLOROACETIL- ACETATE IN THE PRESENCE OF POTASSIUM CARBONATE
}

\author{
G.G. Ibrahimova ${ }^{1,2}$ \\ ${ }^{I}$ Ganja State University \\ 425, G.Aliyev ave., AZ 2001, Ganja, Azerbaijan; e-mail: gulay_gulay87@mail.ru \\ ${ }^{2}$ Baku State University \\ Z.Xalilov str., 23, Baku AZ 1148, Azerbaijan Republic
}

Received 18.12.2019

\begin{abstract}
The reaction of self-condensation of methyl 4-chloroacetylacetate in the presence of potash both in dimethylsulphoxide environment and without its participation was studied following which 1,4dimetildicarboxylate-2,5-cyclohexadione and 1,4-dimethyl-dicarboxylatedihydroquinone were obtained, respectively. A mechanism for the formation of these compounds was proposed. With the participation of dimethylsulfoxide, the reaction proceeds in two stages: intermolecular condensation with subsequent intramolecular condensation and the participation of the active methylene unit and the chloromethylene fragment. Without participation of the solvent, in excess of potash, the obtained intramolecular condensation product during the intensive release of energy was aromatized to form 1,4-dimethyl dicarboxylate dihydroquinone.
\end{abstract}

Keywords: condensation, potash, dimethyl dicarboxylate acetone, methyl-4-chloro-acetylacetate, enol form, hydroquinone.

DOI: $10.32737 / 2221-8688-2020-1-92-96$

\section{Introduction}

Polycarbonyl compounds and their derivatives are typical representatives of substances with an active methylene group, synthetic precursors of many natural and pharmacological compounds [1-6].

The interaction of polycarbonyl compounds with halogen alkanes provides an opportunity for alternative reactions progress, the direction of which can be changed by choosing appropriate conditions and nature for reacting compounds $[7,8]$.

The low yield of alkylation products of dimethylacetone dicarboxylate (I) with monoand polyhalogen alkanes $[9,10]$ gives reason to suggest that along with the alkylation reaction there is a competitive reaction involving only compound without an alkylating reagent.

\section{Experimental part}

The ${ }^{1} \mathrm{H}$ and ${ }^{13} \mathrm{C}$ NMR spectra were taken on a Bruker AV-300 [300 (1H) and 75 (13C) $\mathrm{MHz}$ ] instrument, the internal standard was TMS. X-ray analysis was performed on a Bruker APEX II device.

\section{1,4-dimethyldicarboxylate-2,5-} cyclohexadione (1). $10 \mathrm{~g}$ (0.06) mol. of methyl 4-chloroacetylacetate was added with stirring to a mixture of $17 \mathrm{~g}(0.12 \mathrm{~mol})$ of potassium carbonate in $50 \mathrm{ml}$ of DMSO. The mixture was stirred for 3 hours at a room temperature and 10 hours at $60^{\circ} \mathrm{C}$. The reaction mixture was cooled, treated with water, after that there were formed suspended particles. It was filtered, and the filtrate was treated with ether, the extract was dried with $\mathrm{Mg}_{2} \mathrm{SO}_{4}$, the solvent distilled off, the yellow crystals of compound 1 precipitated out. The yield $14 \mathrm{~g}$ (52\%), mp 152-153 ${ }^{\circ}$ C. Found,\%: C 52.78; $\mathrm{H} 5.17 \quad \mathrm{C}_{10} \mathrm{H}_{12} \mathrm{O}_{6}$ Calculated,\%: C $52.63 ; \mathrm{H} 5.26$

NMR $1 \mathrm{H}(\delta \mathrm{mh}): 3.2 \mathrm{~s}(2 \mathrm{H}, \mathrm{CH} 2), 3.8 \mathrm{~s}(3 \mathrm{H}$, $\mathrm{CH} 3 \mathrm{O}), 3.9 \mathrm{~s}(3 \mathrm{H}, \mathrm{CH} 3 \mathrm{O}), 7.45 \mathrm{~s}(1 \mathrm{H}, \mathrm{CH}=)$, $9.8 \mathrm{~s}(1 \mathrm{H}, \mathrm{OH}), 12.1 \mathrm{~s}(1 \mathrm{H}, \mathrm{OH})$. NMR $13 \mathrm{C}(\delta$ 
m.h. $): 28.42\left(\mathrm{CH}_{2}\right), 52.33\left(\mathrm{OCH}_{3}\right), \quad 53.07$ $\left(\mathrm{OCH}_{3}\right), 95.94(\mathrm{CH}), 118.00(\mathrm{CH}$, enol $)$, $120.05(\mathrm{CH}$, enol), $151.32(=\mathrm{CH}), 168.00$ $(\mathrm{C}=\mathrm{O}), 171.36(\mathrm{C}=\mathrm{O})$.

\section{1,4-Dimethyldicarboxylatedihydro-}

quinone (2). A mixture of $40 \mathrm{~g}(0.28 \mathrm{~mol})$ of potassium carbonate and $10 \mathrm{~g}(0.06 \mathrm{~mol})$ of methyl 4-chloroacetylacetate was stirred for 3 hours at $15-20{ }^{\circ} \mathrm{C}$. From the coffee-coloured solution, yellow crystals of potassium dihydroquinone 1,4-dimethyl dicarboxylate precipitated. The precipitated crystals were treated with $\mathrm{HCl}$; crystals of compound $\mathbf{2}$ precipitate from solution. Theyieldwas $7.8 \mathrm{~g}(41 \%)$, mp 158160 C. Found,\%: C 52.68; H 4.57 $\mathrm{C}_{10} \mathrm{H}_{12} \mathrm{O}_{6}$ Calculated,\%: $\mathrm{C} \quad 53.09 ; \quad \mathrm{H}$ 4.42. $\mathrm{NMR}^{1} \mathrm{H}(\delta$ m.h. $): 3.86$ c $\left(6 \mathrm{H}, 2 \mathrm{CH}_{3} \mathrm{O}\right)$, $7.26 \mathrm{c}(2 \mathrm{H}, 2 \mathrm{CH}=$ arom. $), 9.66 \mathrm{c}(2 \mathrm{H}, 2 \mathrm{OH})$. $\mathrm{NMR}^{13} \mathrm{C}, \delta$ m.h.: 53.10 $\left(\mathrm{OCH}_{3}\right), 118(\mathrm{CH}$, arom. $), 120.46(\mathrm{CH}$, arom $), 151.02(=\mathrm{CH}$, arom), $167.81(\mathrm{C}=\mathrm{O})$.

\section{Results and discussion}

The structural similarity of dimethyl dicarboxylate acetone and methyl 4-chloroacetylacetate suggests that the latter in an alkaline medium can undergo the selfcondensation with the ester group, as it occurs with dimethyl 1,3-dicarboxylateacetone [10] and the participation of active chloromethylene fragment.

Of interest was the reaction of selfcondensation of methyl 4-chloroacetylacetate in the presence of potash in two cases: in dimethylsulfoxide (variant A) and without the solvent (variant B). Analysis of the product of self-condensation of methyl 4-chloroacetate in DMSO in the presence of potash showed that in the process of condensation the ester group was not affected and the reaction proceeds with the participation of the active methylene group and the chloromethylene unit to form 1,4-dimethyl dicarboxylate-2,5-cyclohexadione (1). The mechanism of formation of the latter can be represented by the following scheme:

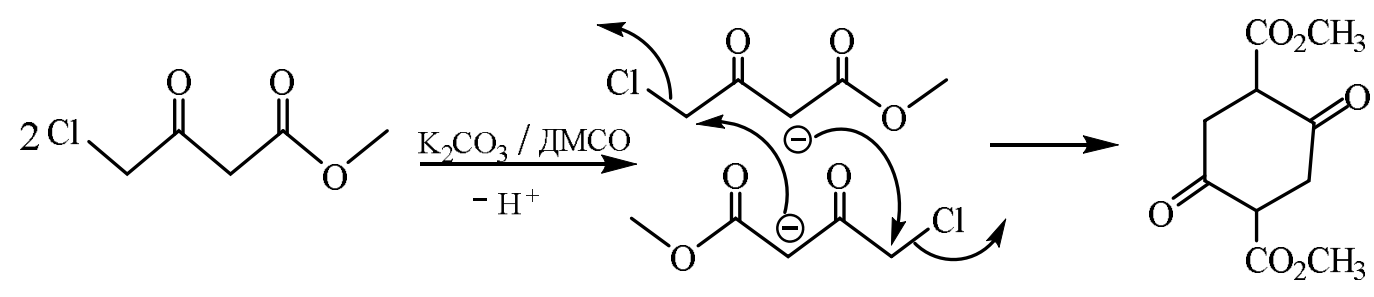

1
The scheme shows a one-step process of the product formation 1, although it' $d$ be preferable to assume that this process proceeds in two stages. At the first stage, intermolecular condensation occurs with the participation of the active methylene group and the chlorine of the methylene fragment. At the second stage, intramolecular condensation also occurred with the participation of the active methylene group and the chloromethylene fragment with the formation of product 1. Certainly, the course of the reaction along this path was caused by the activity of the chlorine atom under the action of the adjacent carbonyl group. The structure of compound 1 was proved by $1 \mathrm{H}$ and 13C NMR spectra. According to NMR data, compound 1 mainly exists in the enol form. The alkylation reaction of compound 1, which was accompanied by the formation of an O-alkylated product, also confirms the enol structure of product 1 . 


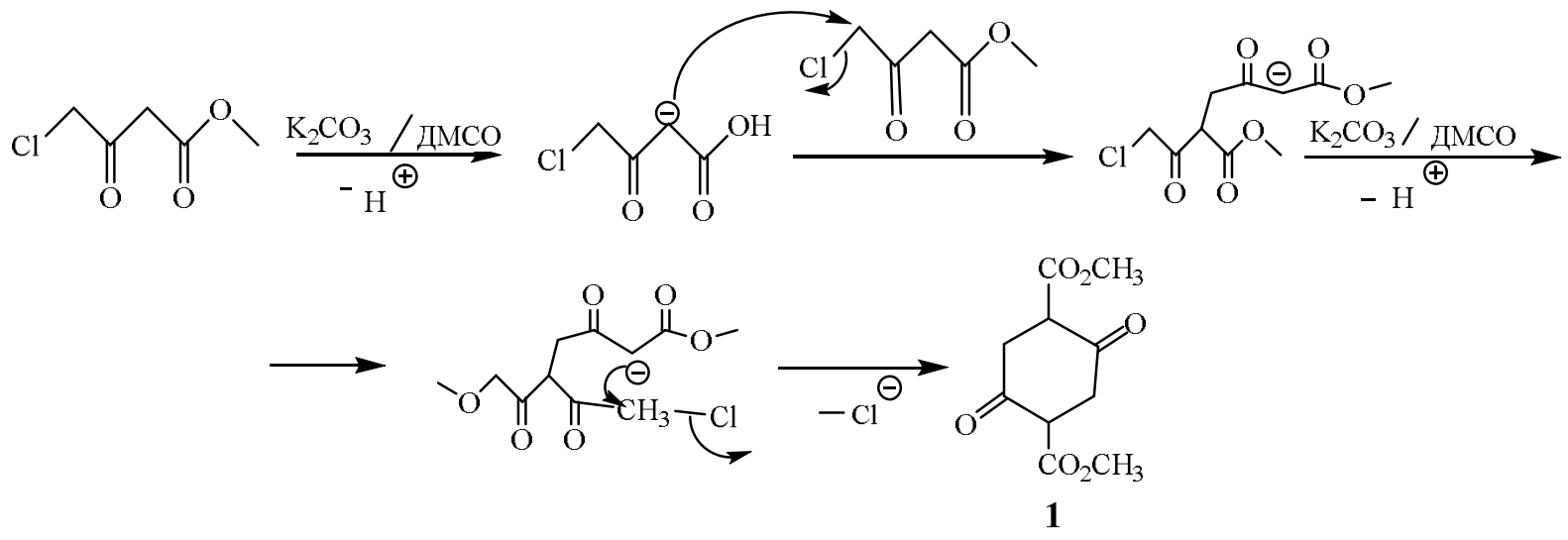

It should be noted that this condensation in the dimethyl dicarboxylate was formed. The presence of potash without solvent proceeds further acidifying produced the corresponding rapidly with the release of energy as a result of 1,4-dimethyl dicarboxylate of hydroquinone 2 which the potassium salt of hydroquinone 1,4- [10].

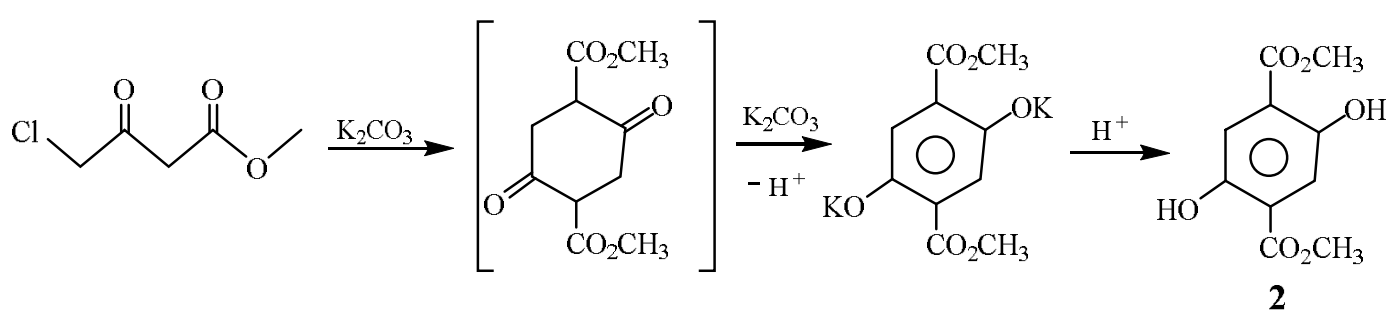

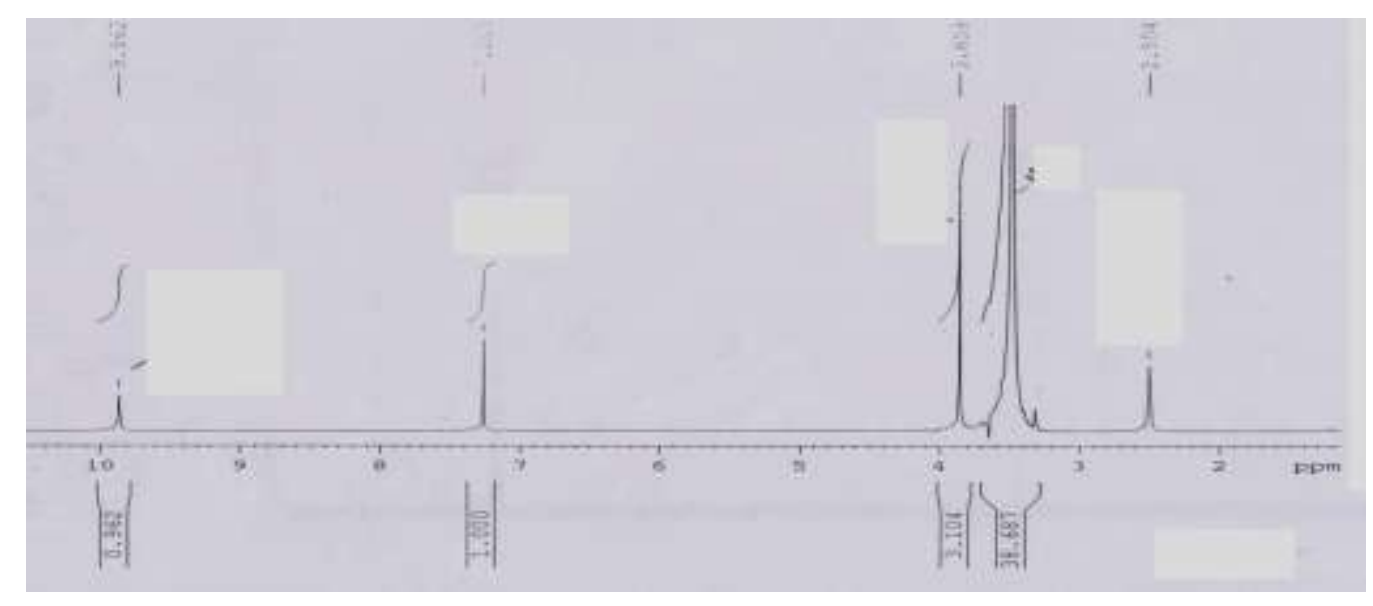

Fig. $2{ }^{1} \mathrm{H}$ NMR spectra of compound 2

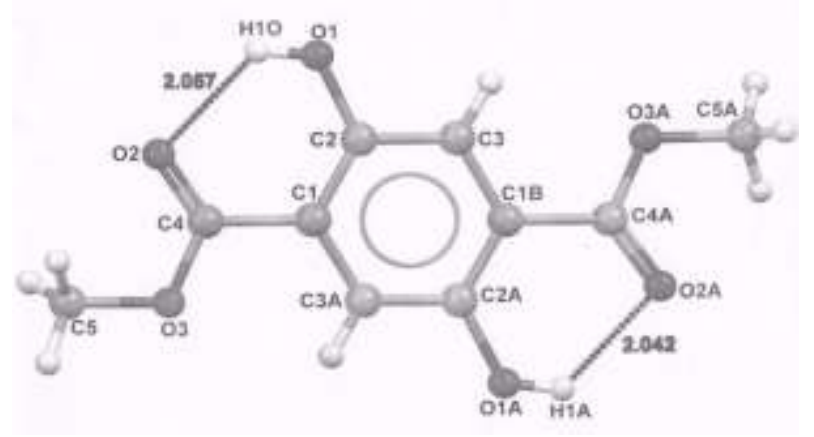

Fig.3. Molecular structure of compound 2 
It should be assumed that methyl 4chloroacetyl acetate was initially transformed into compound 1 under the action of potash which under conditions of potash excess with energy release was aromatized into compound 2. The structure of compound 2 was confirmed by ${ }^{1} \mathrm{H}$ and ${ }^{13} \mathrm{C}$ NMR spectra (Fig. 2), as well as $\mathrm{X}$-ray analysis (Fig. 3)

\title{
Reference
}

1. Stone M.J., Maplesfone R.A., Rahman S.K. and Williams D.H. Synthesis of 3,5dihydroxyphenylglicine derivatives and the C-terminal dipeptide of vancomycin. Tetrahedron Letters, 1991, vol. 32, no. 23, p. 2663.

2. Kislyi V.P., Shestopalov A.M., Kagramanov N.D., Semenov V.V. Synthesis of 3-nitropyrid-2(1H)-ones from C-nitroacetamid and 1,3-dicarbonyl compounds Russ.Chem.Bull, 1997, vol. 46, p.539.

3. Shchegolkov E.B., Burgart Y.V., Khudina O.G., Saloutin V.I.and Chupaktin O.N. 2(Het)arylhydrazono-1,3-dicarbonye compounds in organic synthesis. Russian Chemical Reviews. 2010, vol. 79, no. 1, p. 33.

4. Kraus G.A., Wan Z.W. Furan synthesis via a $4+1$ ring-building strategy - anapproach to 1,3-diacylfurans. Synlett, 1997, no. 11, p.1259.

5. Langer P. Regio- and diastereoselective cyclization reactions of free and masked 1,3-dicarbonyl dianions, with 1,2dielektrophiles. Chem. Eur. J., 2001, vol. 7, p. 3858 .
6. Tyvorskii V., Bobrov D., Kulinkovich O. New synthetic approaches to 2-perfluoroalkyl-4H-pyran-4- ones. Tetrahedron, 1998, vol.54, no. 10, p. 2819.

7. Krolin K., Bernhard S., Florke U., Hayat N. Biomimetic-type synthesis of benzo[ $\alpha]$ naphthacenequinones related to pradimicinone. J.Org. Chem., 2000, vol. 65, p. 3218.

8. Dietmar Schmidt, Chandi C. Malakar and Uwe Beifuss. 2.3-Dihalo-1-propenes as bilding bloks in $\mathrm{Cu}(\mathrm{I})$-catalyzed domino reaktions: Efficient and selektive synthesis of furans. Org. Lett. 2014, vol. 14, no.16, p. 1234.

9. Luo, Yunfel, Cornell, Andrew J. Chemoenzymatic synthesis and application of bicyclo[2.2.2] octadiene ligandsi increased efficienty in rhodium-catalyzed asymmetric conjugate additions by electronic tuning. Angewante chemie, 2010, vol. 49, no. 15, p. 2750.

10. Ismailov V.M., Ibragimova G.G., Sadykhova N.D., Mamedova I.A., Yusubov N.N. Alkylation of methyl 4-chloro-3oxobutanoate with di- and tribromoalkanes. Russ. J. of Org.Chem. 2017, vol. 53, no. 7, p.1099.

\section{METIL-4-XLORASETILASETATIN POTAS MÜHİTINDӘ ÖZÜOKSIDLOŞMӘ REAKSIYASI BARADӘ}

\author{
G.H. Ibrahimova ${ }^{1,2}$ \\ ${ }^{1}$ Ganca Dövlat Universiteti \\ AZ 2001, Gancə şəh.,H.Oliyev pr., 425 \\ ${ }^{2}$ Bakı Dövlat Universiteti \\ AZ 1148 Bakl, Z.Xalilov küç., 23
}

\begin{abstract}
Metil-4-xlorasetilasetatat potaşın iştiraki ila dimetilsulfoksid mühitində vo onun iştiraki olmadan özükondenslaşma reaksiyası naticasinda 1,4-dimetildikarboksilat-2,5-tsikloheksadion va 1,4dimetildikarboksilat dihidroxinonun alınması öyranilmişdır. Göstərilan birlaşmalorin alınma mexanizmi taklif edilmişdir. Dimetilsulfoksid mühitinda reaksiya iki marhaladon ibaratdirmolekulalar arası kondenslaşma va sonrakı marhalado aktiv metilen zancir va xlormetilen
\end{abstract}


fraqmentin iştirakila molekula daxili kondeslaşmə gedir. Halledicinin iştraki olmadan, potaşın artıq miqdarda oldugu halda molekula daxili kondesloşmə məhsulu intensiv enerjinin ayrlması naticasinda aromatikilaşir va naticada 1,4-dimetildikarboksilat dihidroxinon alınır.

Acar sözlor: kondesləşmə, potaş, dimetildikarboksilataseton, metil-4-xlorasetilasetat, enol, hidroxinon.

\title{
О РЕАКЦИИ САМОКОНДЕНСАЦИИ МЕТИЛ-4-ХЛОРАЦЕТИЛАЦЕТАТА В ПРИСУТСТВИИ ПОТАША
}

\author{
Г.Г. Ибрагимова ${ }^{1,2}$ \\ ${ }^{1}$ Гянджинский государственный университет \\ AZ 2001,Гянджа, пр.Г.Алиева, 425 \\ ${ }^{2}$ Бакинский государственный университет \\ AZ 1148 Баку, ул. 3.Халилова, 23 \\ e-mail: gulay_gulay87@mail.ru
}

Изучена реакция самоконденсаџии метил-4-хлорацетилацетата в присутствии поташа как в среде диметилсульфоксида, так и без его участия, в результате которой получены соответственно 1,4-диметилдикарбоксилат-2,5-циклогексадион $\quad$ и 1,4диметилдикарбоксилат дигидрохинона. Предложен механизм образования указанных соединений. При участии диметилсульфоксида реакция протекает в два этапа межмолекулярная конденсация с последующей внутримолекулярной конденсацией c участием активного метиленового звена и хлорметиленого фрагмента. Без участия растворителя, в избытке поташа образовавший продукт внутримолекулярной конденсации при интенсивном выделении энергии ароматизируется с образованием 1,4-диметилдикарбоксилат дигидрохинона.

Ключевые слова: конденсация, поташ, диметилдикарбоксилатацетон, метил-4хлорацетилачетат, енольная форма, гидрохинон. 